\title{
Nominal EXCHANGE RATE FLEXIBILITY AND REAL EXCHANGE RATE ADJUSTMENT: EVIDENCE FROM DUAL EXCHANGE RATES IN DEVELOPING COUNTRIES
}

\author{
YIN-WONG CHEUNG \\ KON S. LAI
}

\author{
CESIFO WORKING PAPER NO. 1512 \\ CATEgORY 6: MONETARy POLICY AND INTERNATIONAL FINANCE \\ JULY 2005 \\ PRESENTED AT CESifo AREA CONFERENCE ON \\ MACRO, MONEY \& INTERNATIONAL FinANCE, FEBRUARY 2005
}

An electronic version of the paper may be downloaded

- from the SSRN website:

www.SSRN.com

- from the CESifo website:

www.CESifo.de 


\title{
NOMINAL EXCHANGE RATE FLEXIBILITY AND REAL EXCHANGE RATE ADJUSTMENT: EVIDENCE FROM DUAL EXCHANGE RATES IN DEVELOPING COUNTRIES
}

\begin{abstract}
This study investigates whether exchange rate flexibility aids real exchange rate adjustment based on intra-period data on dual exchange rates from developing countries. Specifically, it analyzes whether the flexible parallel market rate produces faster or slower real exchange rate adjustment than the much less flexible official rate does. Half-life estimates of adjustment speeds are obtained using fractional time series analysis. We find no systematic evidence that greater exchange rate flexibility tends to produce faster or slower real exchange rate adjustment, albeit there is substantial heterogeneity in speed estimates across countries. With officially pegged exchange rates, developing countries often use parallel exchange markets as a back-door channel to facilitate real exchange rate adjustment, but the empirical evidence suggests that these parallel markets in most cases fail to help promote real rate adjustment.
\end{abstract}

JEL Code: C22, F31.

Keywords: real exchange rate, fractional time series, half life.

\author{
Yin-Wong Cheung \\ Department of Economics \\ University of California \\ Santa Cruz, CA 95064 \\ USA \\ cheung@ucsc.edu
}

\author{
Kon S. Lai \\ Department of Economics \\ California State University \\ Los Angeles, CA 90032 \\ USA \\ klai@calstatela.edu
}

The authors would like to thank Ansgar Belke, Michael Binder, Stephen Ching, Dave Cook, Jakob De Haan, Mathias Hoffman, Hans Genberg, Paul De Grauwe, Paul Lau, Ronald MacDonald, Assaf Razin, Anne Sibert, Alan Siu, Keith Wong, James Yetman, and participants of the 2005 CESifo Area Conference on Macro, Money and International Finance, and the seminars at the University of Hong Kong, the University of Science and Technology, and the HKIMR for their comments and suggestions. 


\section{Introduction}

The role of exchange rate flexibility in economic adjustment has long been a hotly contested issue. Nurkse (1944) concludes from interwar experience that speculative exchange rate movements amplify and prolong disequilibria rather than accelerate economic adjustment. Such sentiment led to the postwar system of pegged rates under the Bretton Woods (BW) agreement. In contrast, Friedman (1953) contends that it is easier for the economy to adjust to shocks by securing needed changes in the real exchange rate through exchange rate than through price adjustment. Instead of fearing the instability flexible rates might bring, Friedman suggested that speculative movements would actually quicken exchange rate adjustment and hasten its equilibrating process. As the BW arrangement grew increasingly strained with currency crises in the late 1960s, many economists began advocating greater exchange rate flexibility.

Since the move to the current float, real exchange rates seem to have grown more persistent. Rogoff (1996) points out that the observed speed of real exchange rate adjustment is puzzlingly slow under the current float. The implication that exchange rate flexibility can actually slow down rather than speed up real exchange rate adjustment casts doubt on the equilibrating function of the nominal exchange rate.

The issue then arises as to whether greater exchange rate flexibility promotes real exchange rate adjustment. Previous empirical results based on cross-period comparisons are far from selfevident. On one end, the inter-period difference in persistence may suggest that real shocks are more significant in the post-BW than in the BW period. Under this interpretation, the change in real exchange rate persistence is a result more of the historical period than of the nominal exchange rate regime (Grilli and Kaminsky, 1991). At the other end, the rise in real exchange rate persistence under floating rates can be viewed as evidence that greater exchange rate flexibility undermines rather than promotes real exchange rate adjustment. According to this view, speculative forces may send the nominal exchange rate temporarily off its equilibrating path. Consequently, exchange rate fluctuations not only introduce an extraneous source of variability but also decelerate the process of real exchange rate adjustment. ${ }^{1}$

\footnotetext{
${ }^{1}$ Recent studies by Engel and Morley (2001) and Cheung et al. (2004) find that the glacial speed of real exchange rate adjustment may come largely from slow nominal exchange rate adjustment rather than from slow price adjustment. The finding raises question about the facilitating role typically expected from nominal exchange rate adjustment.
} 
These opposing interpretations underscore a basic problem with cross-period comparison analysis. Different historical periods can differ not only in the exchange rate regime but also in international events (such as oil crises) and domestic economic conditions. Unless the statistical analysis can fully control for all relevant inter-period differences in both global and domestic economic conditions, it is difficult to determine in cross-period analysis the true extent to which the change in exchange rate flexibility is responsible for the observed change in the real exchange rate adjustment speed.

In this study, we do not analyze exchange rate flexibility in usual terms of exchange rate regimes (floating as opposed to fixed), but in terms of dual exchange rates (market-determined as opposed to government-set) from developing countries. The former approach requires crossperiod analysis, whereas the latter permits within-period analysis. Moreover, for many developing countries, the official exchange rate regime classification can be misleading in the presence of dual exchange rates, which make it less than straightforward to determine the true de facto regime (Reinhart and Rogoff, 2004).

This study provides evidence from dual exchange rate systems on the issue in whether exchange rate flexibility aids real exchange rate adjustment. Not only during the BW period but also afterwards, parallel markets for foreign exchange - especially for the U.S. dollar - were common among developing countries. Unlike the official rate, which is fixed and occasionally reset by the relevant monetary authority, the parallel rate is determined by market demand and supply. With limited access to the official exchange market, the parallel market serves to meet unsatisfied demand for foreign currency. Many developing countries use the dual exchange rate system as a tool to stabilize the real economy and to insulate real economic activity from the volatility of financial markets (Pozo and Wheeler, 1999). As noted by Reinhart and Rogoff (2004), parallel exchange rates provide a form of "back-door" floating in a lot of countries where an official peg is adopted.

The spread between the parallel and the official exchange rate - referred to as the parallel market premium - often works as an indicator of exchange rate misalignments and has been used as a guide to realigning the official rate. According to Reinhart and Rogoff (2004), the parallel exchange rate is "a far better barometer of monetary policy than is the official exchange rate" and that the parallel market premium often correctly predicts realignments in the official rate and anticipates future official rate changes. Earlier studies of the parallel market premium 
(Dornbsuch et al., 1983; Kamin, 1993; Monteil and Ostry, 1994; Pozo and Wheeler, 1999) also suggest an important role for the expectations of future official rate changes in driving the premium. Ghei and Kamin (1999) recognize that the parallel exchange rate is a good, though not entirely perfect, proxy for the free-market currency value.

To examine whether greater exchange rate flexibility leads to quicker real exchange rate adjustment, this study analyzes data on dual exchange rates for 24 developing countries. For each of these countries, a parallel market for foreign exchange exists alongside the official one during both BW and post-BW periods. With official and parallel rates being available for the same historical period, this special data set permits intra-period analysis. We can evaluate he relative adjustment speed of the real official and the real parallel rate for each country within a given time period. This minimizes the need to control for any inter-period differences in economic conditions. Two questions of interest are: Do the official and the parallel market rate revert toward one another over time? Does the flexible parallel market rate imply a faster speed of real exchange rate adjustment than the less flexible official rate?

In addition to analyzing the difference in adjustment speed between real official and parallel rates on a country-by-country basis, this study also shows that the speed of adjustment for either rate can vary considerably across countries, even within the same historical period. A crosssection analysis will be conducted to evaluate how much the cross-country variation in adjustment speeds is attributable to structural differences in the underlying economies.

\section{Empirical Methodology}

The adjustment dynamics of economic processes will be evaluated based on fractional time series models. Fractional processes can exhibit a wide variety of adjustment dynamics, not captured by standard time series models (Diebold et al., 1991; Cheung and Lai, 1993). Indeed, these processes provide a better approximation to the Wold decomposition of time series dynamics than conventional processes (Granger and Joyeux, 1980; Hosking, 1981). Fractional processes are in general represented by

$$
B(L)(1-L)^{d} y_{t}=D(L) v_{t}
$$

where $y_{t}$ is the time series under consideration, $L$ is the standard lag operator, $B(L)=1-\beta_{1} L-$ $\ldots-\beta_{p} L^{p}, D(L)=1-\delta_{1} L-\ldots-\delta_{q} L^{q}$, all roots of $B(L)$ and $D(L)$ are stable, $v_{t}$ is the random error 
term, and the fractional differencing part is

$$
(1-L)^{d}=\sum_{m=0}^{\infty} \frac{\Gamma(m-d) L^{m}}{\Gamma(m+1) \Gamma(-d)}
$$

with $\Gamma(\cdot)$ being the gamma function. This model describes a broad class of time series

processes known as autoregressive fractionally integrated moving-average (or $\operatorname{ARFIMA}(p, d, q)$ ) processes. It extends the standard $\operatorname{ARMA}(p, q)$ and $\operatorname{ARIMA}(p, 1, q)$ models by permitting noninteger values of $d$. Such extended flexibility in modeling dynamics can be important for a proper evaluation of economic adjustment. The long-run reversion property of $y_{t}$ is determined by the fractional integration parameter, $d$. Cheung and Lai (1993) show that mean reversion occurs so long as $d<1$.

In our statistical analysis, a frequency-domain maximum likelihood procedure is used to estimate the $\operatorname{ARFIMA}(p, d, q)$ model. Following Fox and Taqqu (1986), we utilize the property that maximizing the likelihood function is asymptotically equivalent to:

$$
\text { Minimizing } \sum_{k=1}^{T-1} \frac{I_{y}(2 \pi k / T)}{f_{y}(2 \pi k / T ; \xi)} \text { with respect to } \xi=\left(d, \beta_{1}, \ldots, \beta_{p}, \delta_{1}, \ldots, \delta_{q}\right)
$$

where

$$
\begin{aligned}
& f_{y}\left(\lambda_{k}, \xi\right)=\left|1-\exp \left(i \lambda_{k}\right)\right|^{-2 d}\left|B^{-1}\left(\exp \left(-i \lambda_{k}\right)\right) D\left(\exp \left(-i \lambda_{k}\right)\right)\right|^{2} \\
& I_{y}\left(\lambda_{k}\right)=\frac{1}{2 \pi T}\left|\sum_{t=1}^{T} y_{t} \exp \left(i \lambda_{k} t\right)\right|^{2}=\frac{1}{2 \pi T}\left[\left(\sum_{t=1}^{T} y_{t} \cos \left(\lambda_{k} t\right)\right)^{2}+\left(\sum_{t=1}^{T} y_{t} \sin \left(\lambda_{k} t\right)\right)^{2}\right]
\end{aligned}
$$

with $\lambda_{k}=2 \pi k / T$ and $i$ being the imaginary part of the complex number. Specifically, $I_{y}\left(\lambda_{k}\right)$ gives the periodogram of $y_{t}$ at the $k$ th Fourier frequency, and $f_{y}\left(\lambda_{k}, \xi\right)$ is proportional to the spectral density of $y_{t}$ at frequency $\lambda_{k}$. The resulting estimator for $d$ is consistent and has an asymptotic normal distribution (Tanaka, 1999). Cheung and Diebold (1994) show that this maximum likelihood procedure for estimating fractional processes has good finite-sample properties.

\section{Preliminary analysis on the parallel market premium}

Before analyzing the relative adjustment speed of the real official and the real parallel exchange rate, we first address some known issues concerning the behavior of the parallel market premium. Let $e_{O t}$ and $e_{P t}$ be, respectively, the official and the parallel market rate in logarithms. The parallel market premium is given by $e_{P t}-e_{O t}$. Although infrequently done, a 
monetary authority may adjust the official rate to reduce currency misalignments. If the parallel market premium is a good gauge of the degree of misalignment and a useful guide for setting the official rate, the official and parallel rates should not drift too far apart. It follows that a long-run stationary relationship likely exists between these two rates. Theoretical models - including portfolio balance models (Dornbusch et al, 1983; Phylaktis, 1991) and monetary models

(Phylaktis, 1996; Kouretas and Zarangas 1998) - also suggest the parallel market premium be stationary.

The parallel market premium may also reflect part of the deviation from purchasing power parity (PPP). To illustrate, we consider a simple variant of the parallel exchange rate models discussed by Kouretas and Zarangas (1998) and Diamandis (2003), under which both financial and goods arbitrages take place in the parallel foreign exchange market. All the model variables are in logarithms. Financial arbitrageurs exploit any divergence between the official and the parallel market rate, and their net supply of foreign exchange in the parallel market is described by

$$
S_{P t}=\theta_{0}+\theta_{1}\left(e_{P t}-e_{O t}\right), \quad \theta_{1}>0
$$

where $e_{P t}$ is the parallel market rate and $e_{O t}$ is the official rate (all expressed as domestic currency per US dollar). This indicates that as the parallel market premium increases, so does the profit incentive to meet demand for foreign exchange in the parallel market. Goods arbitrages, on the other hand, are carried out based on the differential between the foreign price $\left(p_{F t}\right)$ and the domestic price $\left(p_{D t}\right)$. Since demand for foreign exchange rises as foreign goods become cheaper relative to domestic goods, the net demand for foreign exchange from goods arbitrageurs in the parallel market is specified as

$$
D_{P t}=\zeta_{0}+\zeta_{1}\left(p_{D t}-e_{P t}-p_{F t}\right), \zeta_{1}>0
$$

where $p_{D t}-e_{P t}$ gives the domestic price in foreign currency units (i.e., in U.S. dollars). At market equilibrium (i.e., when $S_{P t}=D_{P t}$ ), equations (A.1) and (A.2) combine to yield the following condition:

$$
e_{P t}-e_{O t}=\varphi_{0}+\varphi_{1}\left(\bar{e}_{t}-e_{O t}\right)
$$

where $\varphi_{0}=\left(\zeta_{0}-\theta_{0}\right) /\left(\theta_{1}+\zeta_{1}\right), \varphi_{1}=\zeta_{1} /\left(\theta_{1}+\zeta_{1}\right)$, and $\bar{e}_{t}=p_{D t}-p_{F t}$ is the PPP-implied equilibrium rate. To the extent that PPP prevails in the long run, the parallel market premium, $e_{P t}-e_{O t}$, is stationary, implying the existence of a long-run equilibrium relation between $e_{P t}$ and $e_{O t}$. 
Table 1. The mean absolute size of nominal exchange rate movements*

\begin{tabular}{|c|c|c|c|c|}
\hline \multirow[b]{2}{*}{ Country } & \multicolumn{2}{|c|}{ Bretton Woods } & \multicolumn{2}{|c|}{ Post-Bretton Woods } \\
\hline & Official rate & Parallel rate & Official rate & Parallel rate \\
\hline Argentina & 2.38 & 4.02 & 8.24 & 9.40 \\
\hline Bolivia & 0.59 & 1.59 & 4.20 & 5.47 \\
\hline Brazil & 3.09 & 4.61 & 9.12 & 9.78 \\
\hline Chile & 2.42 & 5.42 & 2.56 & 3.57 \\
\hline Colombia & 1.25 & 2.44 & 1.61 & 2.27 \\
\hline Costa Rica & 0.09 & 1.55 & 1.52 & 2.83 \\
\hline Dominican Republic & 0.00 & 3.19 & 1.47 & 2.38 \\
\hline Ecuador & 0.27 & 1.97 & 1.96 & 3.00 \\
\hline Egypt & 0.11 & 3.83 & 0.77 & 2.74 \\
\hline El Salvador & 0.00 & 1.25 & 0.49 & 3.94 \\
\hline India & 0.45 & 2.85 & 1.31 & 2.84 \\
\hline Israel & 0.44 & 1.83 & 3.50 & 4.98 \\
\hline Korea & 1.13 & 3.08 & 1.06 & 2.59 \\
\hline Malaysia & 0.16 & 0.62 & 1.26 & 1.73 \\
\hline Mexico & 0.00 & 0.03 & 2.71 & 3.46 \\
\hline Morocco & 0.16 & 1.98 & 1.82 & 2.58 \\
\hline Pakistan & 0.56 & 3.07 & 0.58 & 2.35 \\
\hline Paraguay & 0.39 & 1.38 & 1.19 & 2.67 \\
\hline Philippines & 0.70 & 2.41 & 1.28 & 2.79 \\
\hline South Africa & 0.19 & 1.51 & 2.10 & 5.31 \\
\hline Sri Lanka & 0.22 & 3.62 & 1.54 & 2.33 \\
\hline Thailand & 0.04 & 0.99 & 0.83 & 2.46 \\
\hline Uruguay & 3.14 & 4.52 & 3.39 & 3.91 \\
\hline Venezuela & 0.24 & 0.33 & 1.89 & 3.34 \\
\hline
\end{tabular}

* All the numbers reported in this table are expressed in percentage terms.

This study examines time series data from 24 developing countries for which exchange rate and price data are available for both BW and post-BW periods. Data on both monthly consumer prices and official exchange rates were taken from the IMF's International Financial Statistics database. As studied by Reinhart and Rogoff (2004), parallel market rates are from various issues of Pick's Currency Yearbook and Pick's World Currency Report (later became the World Currency Yearbook). All exchange rates are expressed in units of foreign currency per U.S. dollar. Dictated by data availability, the sample data cover the period January 1957 through 
December 1998. ${ }^{2}$ The countries under study include Argentina, Bolivia, Brazil, Chile, Colombia, Costa Rica, Dominican Republic, Ecuador, Egypt, El Salvador, India, Israel, Korea, Malaysia, Mexico, Morocco, Pakistan, Paraguay, Philippines, South Africa, Sri Lanka, Thailand, Uruguay, and Venezuela. Even during the post-BW period, these countries chose to adopt official pegs or crawls (with fixed or limited flexibility in rates) against the U.S. dollar most of the time.

Unlike previous cross-regime studies, which explore the different flexibility of official rates between the BW and the post-BW period, this study builds on the basic premise that official rates are less flexible than parallel rates within the same period. Our dual-rate analysis requires neither an assumption of official exchange rates being absolutely fixed over time nor an assumption of parallel exchange rates being entirely flexible. ${ }^{3}$ Table 1 shows the average size (measured as the mean absolute change) of official and parallel rate movements over the two time periods. The data are consistent with the conventional wisdom that market-determined parallel rates move more freely than official rates.

Table 2 reports some descriptive statistics showing the average size and standard deviation of the parallel market premium during the BW and post-BW periods. As shown, the parallel market premium can vary greatly both in size and in variability across countries, even within the same period. Moreover, the data reveal no systematic pattern of change in the average premium size across the two time periods. The average parallel market premium rises in 9 countries but falls in 15 countries when moving from the BW to the post-BW period. There is also no systematic pattern of cross-period change in variability, with increases for 10 countries and decreases for 14 countries from the BW to the post-BW period.

\footnotetext{
${ }^{2}$ The World Currency Yearbook had stopped being published after 1998. In addition, due to limited data availability of parallel market rates, a slightly shorter sample period that begins later than 1957 is used in the cases of Dominican Republic, El Salvador, Morocco, and Venezuela. For several countries (Brazil, Costa Rica, Korea, and Thailand), moreover, consumer price data are not available for the sample period. In these cases, we use either wholesale or producer price data.

${ }^{3}$ Most nominal exchange rates are neither completely fixed nor completely flexible over time. This is true for both the BW period and the post-BW period. This is also true for both developing and industrial countries.
} 
Table 2. The average size and variability of the parallel market premium*

\begin{tabular}{|c|c|c|c|c|}
\hline \multirow[b]{2}{*}{ Country } & \multicolumn{2}{|c|}{ Bretton Woods } & \multicolumn{2}{|c|}{ Post-Bretton Woods } \\
\hline & Mean & St. Dev. & Mean & St. Dev. \\
\hline Argentina & 11.60 & 23.60 & 26.34 & 35.25 \\
\hline Bolivia & 12.83 & 15.91 & 23.50 & 47.61 \\
\hline Brazil & 10.26 & 14.34 & 21.06 & 21.26 \\
\hline Chile & 40.17 & 49.46 & 15.24 & 14.72 \\
\hline Colombia & 21.22 & 18.37 & 7.68 & 6.80 \\
\hline Costa Rica & 20.68 & 11.46 & 13.60 & 12.71 \\
\hline Dominican Republic & 24.38 & 9.07 & 23.90 & 23.23 \\
\hline Ecuador & 15.82 & 7.80 & 19.88 & 21.81 \\
\hline Egypt & 74.99 & 23.84 & 42.39 & 39.10 \\
\hline El Salvador & 16.60 & 6.64 & 41.09 & 33.35 \\
\hline India & 38.05 & 15.88 & 12.49 & 7.20 \\
\hline Israel & 16.92 & 9.37 & 9.10 & 12.53 \\
\hline Korea & 34.94 & 32.38 & 4.40 & 6.52 \\
\hline Malaysia & 1.95 & 1.91 & 0.63 & 2.04 \\
\hline Mexico & -0.08 & 0.04 & 8.37 & 13.85 \\
\hline Morocco & 12.05 & 6.87 & 4.39 & 4.30 \\
\hline Pakistan & 54.60 & 18.31 & 12.98 & 10.66 \\
\hline Paraguay & 14.06 & 13.53 & 31.58 & 34.18 \\
\hline Philippines & 22.36 & 25.88 & 6.36 & 6.49 \\
\hline South Africa & 6.87 & 4.51 & 9.16 & 9.58 \\
\hline Sri Lanka & 67.59 & 28.46 & 20.34 & 20.13 \\
\hline Thailand & 1.26 & 2.10 & 0.13 & 3.39 \\
\hline Uruguay & 35.56 & 48.68 & 8.77 & 10.52 \\
\hline Venezuela & 10.41 & 15.55 & 24.69 & 38.72 \\
\hline
\end{tabular}

* The parallel market premium is measured in percentage terms.

Table 3 summarizes the test results from fractional integration analysis by country. The unit-root null hypothesis of $d=1$ is tested against the mean-reverting alternative of $d<1$. For the BW period, the unit-root hypothesis can be rejected for all but one of the 24 countries at the $5 \%$ significance level. The post-BW data also widely reject the unit-root hypothesis. In all but two cases can the unit-root hypothesis be rejected at the 5\% level. In general, the test results strongly support that the differential between the official and the parallel market rate is stationary. Indeed, our findings suggest that these two exchange rates are fractionally 
cointegrated - a more general notion of cointegration than what has been considered in previous studies (e.g., Booth and Mustafa, 1991; Kouretas and Zarangas, 1998). ${ }^{4}$

Table 3. Testing for mean reversion in the parallel market premium*

\begin{tabular}{|c|c|c|c|c|}
\hline \multirow[b]{2}{*}{ Country } & \multicolumn{2}{|c|}{ Bretton Woods } & \multicolumn{2}{|c|}{ Post-Bretton Woods } \\
\hline & $d-1$ & $t$-stat & $d-1$ & $t$-stat \\
\hline Argentina & 0.00 & $(0.01)$ & -0.20 & $(-2.83)^{*}$ \\
\hline Bolivia & -0.06 & $(-3.54)^{*}$ & -0.38 & $(-4.21)^{*}$ \\
\hline Brazil & -0.64 & $(-5.16)^{*}$ & -0.32 & $(-2.94)^{*}$ \\
\hline Chile & -0.06 & $(-1.98)^{*}$ & -0.41 & $(-3.59)^{*}$ \\
\hline Colombia & -0.35 & $(-10.58)^{*}$ & -1.09 & $(-12.58)^{*}$ \\
\hline Costa Rica & -0.79 & $(-6.39)^{*}$ & -0.23 & $(-3.00)^{*}$ \\
\hline Dominican Republic & -0.27 & $(-3.48)^{*}$ & -0.99 & $(-6.92)^{*}$ \\
\hline Ecuador & -0.30 & $(-4.85)^{*}$ & -0.20 & $(-2.38)^{*}$ \\
\hline Egypt & -1.16 & $(-5.34)^{*}$ & 0.09 & $(1.00)$ \\
\hline El Salvador & -0.04 & $(-2.20)^{*}$ & -0.12 & $(-1.99)^{*}$ \\
\hline India & -1.06 & $(-7.91)^{*}$ & -1.08 & $(-8.80)^{*}$ \\
\hline Israel & -1.01 & $(-5.20)^{*}$ & -0.09 & $(-1.15)$ \\
\hline Korea & -0.84 & $(-42.63)^{*}$ & -1.33 & $(-26.61)^{*}$ \\
\hline Malaysia & -0.38 & $(-6.63)^{*}$ & -1.35 & $(-3.43)^{*}$ \\
\hline Mexico & -0.25 & $(-8.54)^{*}$ & -0.64 & $(-8.62)^{*}$ \\
\hline Morocco & -0.32 & $(-4.12)^{*}$ & -1.44 & $(-13.10)^{*}$ \\
\hline Pakistan & -1.41 & $(-5.97)^{*}$ & -0.18 & $(-3.56)^{*}$ \\
\hline Paraguay & -0.89 & $(-4.44)^{*}$ & -0.44 & $(-4.12)^{*}$ \\
\hline Philippines & -0.27 & $(-3.35)^{*}$ & -1.10 & $(-12.42)^{*}$ \\
\hline South Africa & -0.94 & $(-6.62)^{*}$ & -0.41 & $(-8.74)^{*}$ \\
\hline Sri Lanka & -0.08 & $(-2.32)^{*}$ & -0.46 & $(-7.77)^{*}$ \\
\hline Thailand & -1.26 & $(-7.84)^{*}$ & -1.36 & $(-21.38)^{*}$ \\
\hline Uruguay & -0.98 & $(-7.08)^{*}$ & -0.33 & $(-3.82)^{*}$ \\
\hline Venezuela & -1.44 & $(-7.71)^{*}$ & -0.77 & $(-3.78)^{*}$ \\
\hline
\end{tabular}

* The unit-root null hypothesis of $d-1=0$ is tested against the mean-reverting fractional alternative of $d-1<0$. The numbers in parentheses are the $t$-statistics for the corresponding estimates. Statistical significance is indicated by an asterisk $\left({ }^{*}\right)$ for the $5 \%$ level.

It should be noted that although the official and parallel exchange rates display a long-run stationary relationship, their short-run differential can still be large and persistent. From an

\footnotetext{
${ }^{4}$ There is a vast literature on dual exchange rates. In addition to the long-run relationship between official and parallel market rates, previous studies have examined additional issues, including market efficiency, causality, volatility transmission, capital controls, and purchasing power parity. We will move away from these known issues and explore a different issue, namely, the relative speed of real rate adjustment produced by dual exchange rates.
} 
algebraic viewpoint, the parallel market premium represents the difference between the real parallel exchange rate $\left(R E R_{P_{t}}\right)$ and the real official exchange rate $\left(R E R_{O t}\right)$ during the same time period:

$$
e_{P t}-e_{O t}=R E R_{P t}-R E R_{O t}
$$

where $R E R_{P t}=e_{P t}+p_{F t}-p_{D t}$ and $R E R_{O t}=e_{O t}+p_{F t}-p_{D t}$, with $p_{F t}$ being the U.S. price level and $p_{D t}$ being the domestic price level (in logarithms). The short-run differential between $e_{P t}$ and $e_{O t}$ shows the possible difference in the dynamic behavior between the real official and the real parallel exchange rate.

\section{Adjustment speeds of real official and parallel exchange rates}

The adjustment behavior of real official and real parallel exchange rates is examined next. We first check the stationarity of individual real exchange rate series. If PPP holds in the long run, the real official and the real parallel exchange rate should exhibit mean reversion. In analyzing the adjustment behavior of real exchange rates in industrial countries, previous studies generally report greater difficulty in finding mean reversion in flexible-rate than in fixed-rate data. In terms of historical periods, it also seems much harder to detect mean reversion during the post-BW period as opposed to other historical periods. Do similar results apply to the behavior of real exchange rates in developing countries? Compared to those for industrial countries, empirical findings for developing countries have been relatively limited and less extensive. In this regard, our results from dual exchange rates in developing countries may offer an alternative perspective on the dynamics of real exchange rate adjustment.

Table 4 contains the results from tests for stationarity in real exchange rates. For the BW period, the unit-root hypothesis can be rejected at the 5\% significance level in 18 out of 24 cases for real official rates and in 19 out of 24 cases for real parallel rates. For the post-BW period, the unit-root hypothesis can be rejected in 18 out of 24 cases for real official rates and in 17 out of 24 cases for real parallel rates. Hence, the real official and the real parallel exchange rate show little difference in terms of the number of unit-root rejection cases. In the large majority of cases, both real official and parallel rates exhibit mean reversion. This applies to the BW and the post-BW period alike. 
Table 4. Testing for mean reversion in real official and parallel exchange rates +

\begin{tabular}{|c|c|c|c|c|c|c|c|c|}
\hline \multirow[b]{3}{*}{ Country } & \multicolumn{4}{|c|}{ Bretton Woods } & \multicolumn{4}{|c|}{ Post-Bretton Woods } \\
\hline & \multicolumn{2}{|c|}{ Real official rate } & \multicolumn{2}{|c|}{ Real parallel rate } & \multicolumn{2}{|c|}{ Real official rate } & \multicolumn{2}{|c|}{ Real parallel rate } \\
\hline & $d-1$ & $t$-stat & $d-1$ & $t$-stat & $d-1$ & $t$-stat & $d-1$ & $t$-stat \\
\hline Argentina & -0.18 & $(-6.10)^{*}$ & -0.14 & $(-2.05)^{*}$ & -0.25 & $(-3.08)^{*}$ & -0.14 & $(-2.83)^{*}$ \\
\hline Bolivia & -0.75 & $(-6.88)^{*}$ & -0.06 & $(-1.92)$ & -0.50 & $(-8.63)^{*}$ & -0.07 & $(-0.68)$ \\
\hline Brazil & -1.21 & $(-8.56)^{*}$ & -0.10 & $(-2.07)^{*}$ & -0.74 & $(-6.22)^{*}$ & -0.16 & $(-2.90)^{*}$ \\
\hline Chile & -0.95 & $(-4.73)^{*}$ & 0.05 & $(0.86)$ & 0.06 & $(1.18)$ & -0.13 & $(-1.48)$ \\
\hline Colombia & -0.19 & $(-3.31)^{*}$ & -0.83 & $(-6.64)^{*}$ & 0.12 & $(1.71)$ & 0.05 & $(0.99)$ \\
\hline Costa Rica & -0.04 & $(-0.49)$ & -0.85 & $(-8.59)^{*}$ & -1.02 & $(-5.09)^{*}$ & -0.14 & $(-0.80)$ \\
\hline Dominican Republic & -1.09 & $(-6.65)^{*}$ & -1.02 & $(-7.48)^{*}$ & -0.14 & $(-3.95)^{*}$ & -0.93 & $(-12.62)^{*}$ \\
\hline Ecuador & -0.10 & $(-2.07)^{*}$ & -0.03 & $(-0.73)$ & -0.11 & $(-1.39)$ & -0.24 & $(-3.65)^{*}$ \\
\hline Egypt & -0.82 & $(-5.74)^{*}$ & -1.04 & $(-8.76)^{*}$ & 0.06 & $(0.84)$ & -0.20 & $(-3.04)^{*}$ \\
\hline El Salvador & -0.07 & $(-0.88)$ & -0.82 & $(-5.64)^{*}$ & -0.92 & $(-15.97)^{*}$ & -0.87 & $(-4.64)^{*}$ \\
\hline India & -0.94 & $(-3.53)^{*}$ & -1.14 & $(-5.63)^{*}$ & -0.74 & $(-3.27)^{*}$ & -0.73 & $(-3.94)^{*}$ \\
\hline Israel & -0.10 & $(-1.64)$ & -0.70 & $(-4.24)^{*}$ & -0.07 & $(-2.85)^{*}$ & -0.26 & $(-17.18)^{*}$ \\
\hline Korea & -1.05 & $(-4.41)^{*}$ & -0.92 & $(-9.24)^{*}$ & -0.95 & $(-7.95)^{*}$ & -1.02 & $(-4.88)^{*}$ \\
\hline Malaysia & -0.78 & $(-4.51)^{*}$ & -0.11 & $(-2.78)^{*}$ & -1.42 & $(-4.42)^{*}$ & -0.92 & $(-6.75)^{*}$ \\
\hline Mexico & -0.03 & $(-0.81)$ & -0.03 & $(-24.32)^{*}$ & -0.85 & $(-8.05)^{*}$ & -0.10 & $(-2.22)^{*}$ \\
\hline Morocco & 0.04 & $(-0.58)$ & -0.34 & $(-4.28)^{*}$ & 0.07 & $(1.39)$ & -0.03 & $(-0.26)$ \\
\hline Pakistan & -0.03 & $(-3.94)^{*}$ & -0.33 & $(-3.93)^{*}$ & 0.09 & (1.64) & -1.17 & $(-7.56)^{*}$ \\
\hline Paraguay & 0.02 & $(0.57)$ & -0.03 & $(-2.28)^{*}$ & -0.04 & $(-4.59)^{*}$ & -0.02 & $(-17.43)^{*}$ \\
\hline Philippines & -0.68 & $(-5.10)^{*}$ & 0.03 & $(0.58)$ & -0.80 & $(-4.07) *$ & -0.87 & $(-4.16)^{*}$ \\
\hline South Africa & -0.19 & $(-4.12)^{*}$ & -1.29 & $(-5.78)^{*}$ & -0.26 & $(-3.64)^{*}$ & -0.19 & $(-4.08)^{*}$ \\
\hline Sri Lanka & -0.03 & $(-5.43)^{*}$ & -0.06 & $(-1.92)$ & -0.14 & $(-2.40)^{*}$ & -0.03 & $(-0.22)$ \\
\hline Thailand & -1.03 & $(-11.99)^{*}$ & -1.10 & $(-8.08)^{*}$ & -0.96 & $(-12.34)^{*}$ & -1.05 & $(-29.30)^{*}$ \\
\hline Uruguay & -1.09 & $(-4.96)^{*}$ & -0.84 & $(-4.57)^{*}$ & -0.75 & $(-7.20)^{*}$ & 0.04 & $(0.52)$ \\
\hline Venezuela & -0.06 & $(-2.00)^{*}$ & -0.26 & $(-2.97)^{*}$ & -0.15 & $(-2.89)^{*}$ & -0.15 & $(-2.54)^{*}$ \\
\hline
\end{tabular}

$+\quad$ The unit-root null hypothesis of $d-1=0$ is tested against the mean-reverting fractional alternative of $d-1<0$. The numbers in parentheses are the $t$-statistics for the corresponding estimates. Statistical significance is indicated by an asterisk $\left({ }^{*}\right)$ for the $5 \%$ level. 


\subsection{Intra-period comparison of adjustment speeds by country}

We next evaluate how fast the real official and the real parallel exchange rate adjust to shocks. To analyze whether the flexible parallel market rate produces quicker real exchange rate adjustment than the pegged official rate, their adjustment speeds - measured in terms of halflives of shocks to real exchange rates - are computed using impulse response analysis. Based on the ARFIMA model, as described in (1), the half-life can be estimated from a moving average representation of the time series process:

$$
(1-L) y_{t}=A(L) v_{t}
$$

where $\mathrm{A}(\mathrm{L})=1+\alpha_{1} L+\alpha_{2} L^{2}+\alpha_{3} L^{3}+\ldots$ derived from

$$
A(L)=(1-L)^{1-d} \Phi(L)
$$

with $\Phi(L)=B^{-1}(L) D(L)$. The moving average coefficients $\left\{\alpha_{1}, \alpha_{2}, \alpha_{3}, \ldots\right\}$ are often referred to as impulse responses, and they track and measure how much the real exchange rate adjusts in subsequent periods after a unit shock. The calculated half-life indicates how long it takes for the impact of a unit shock to the real exchange rate to dissipate by half.

The question at issue is whether greater exchange rate flexibility facilitates real exchange rate adjustment. The conventional argument is that, in a world of sticky prices, the speed at which the real exchange rate adjusts should depend a lot on exchange rate flexibility. Under pegged exchange rates, real exchange rates are expected to adjust at a slow pace limited by price stickiness. Although exchange rate realignments may sometimes hasten adjustment, they occur infrequently. With flexible exchange rates, on the other hand, real exchange rates can adjust quickly through immediate changes in nominal exchange rates. Despite the intuitive appeal of this argument, verifying its empirical validity is not clear-cut in general. The usual approach is to analyze the difference in real exchange rate behavior between fixed-rate and flexible-rate regimes over different historical periods. Apart from the possible issue in exchange rate regime classifications (Reinhart and Rogoff, 2004), the cross-regime/cross-period comparison presents another problem, namely that different historical periods can have different global and domestic conditions that can alter real exchange rate behavior.

In our analysis of dual exchange rates, the adjustment speed of the real official exchange rate is compared to that of the real parallel exchange rate over the same time period. If nominal exchange rate flexibility aids real exchange rate adjustment, the flexible parallel market rate 
should yield a faster speed of real exchange rate adjustment than does the inflexible official rate. To the extent that the speeds of real official and parallel rates are compared over the same period for the same country, the intra-period country-by-country comparison averts the need to control for economic conditions.

Table 5. Estimates of adjustment speeds for real official and parallel rates*

\begin{tabular}{|c|c|c|c|c|}
\hline \multirow[b]{2}{*}{ Country } & \multicolumn{2}{|c|}{ Bretton Woods } & \multicolumn{2}{|c|}{ Post-Bretton Woods } \\
\hline & $\frac{\text { Real official rate }}{\text { Half-life }}$ & $\frac{\text { Real parallel rate }}{\text { Half-life }}$ & $\frac{\text { Real official rate }}{\text { Half-life }}$ & $\frac{\text { Real parallel rate }}{\text { Half-life }}$ \\
\hline Argentina & 13.97 & 9.86 & 1.29 & 5.31 \\
\hline Bolivia & 5.16 & $100+$ & 0.15 & 0.11 \\
\hline Brazil & 0.61 & 35.30 & 2.08 & 4.88 \\
\hline Chile & 0.73 & $\infty$ & $\infty$ & $100+$ \\
\hline Colombia & 6.25 & 1.12 & $\infty$ & $\infty$ \\
\hline Costa Rica & $100+$ & 1.95 & 0.57 & 80.51 \\
\hline Dominican Republic & 0.69 & 0.44 & 7.02 & 2.84 \\
\hline Ecuador & 58.83 & $100+$ & 34.52 & 13.61 \\
\hline Egypt & 2.56 & 0.48 & $\infty$ & 1.04 \\
\hline El Salvador & 34.33 & 1.91 & 0.64 & 1.37 \\
\hline India & 1.16 & 0.57 & 2.27 & 1.48 \\
\hline Israel & 34.61 & 1.73 & 46.33 & 0.50 \\
\hline Korea & 1.06 & 1.76 & 1.52 & 0.91 \\
\hline Malaysia & 2.07 & 23.56 & 1.22 & 1.45 \\
\hline Mexico & $100+$ & $100+$ & 2.65 & 59.28 \\
\hline Morocco & $\infty$ & 0.73 & $\infty$ & $100+$ \\
\hline Pakistan & $100+$ & 0.71 & $\infty$ & 0.32 \\
\hline Paraguay & $100+$ & $100+$ & $100+$ & $100+$ \\
\hline Philippines & 1.58 & $\infty$ & 1.89 & 1.11 \\
\hline South Africa & 1.60 & 0.39 & 5.70 & 1.80 \\
\hline Sri Lanka & $100+$ & $100+$ & 4.27 & $100+$ \\
\hline Thailand & 0.73 & 0.64 & 1.49 & 0.70 \\
\hline Uruguay & 0.46 & 1.07 & 4.60 & $\infty$ \\
\hline Venezuela & $100+$ & 2.09 & 4.61 & $100+$ \\
\hline
\end{tabular}

* All half-life estimates are expressed in years. For half-life estimates that are longer than 100 years, they are indicated by " $100+$ " in the table. In cases in which the real exchange rate process yields an estimated integration order greater than one (i.e., $d>1$ ), it is indicated by " $\infty$ " and considered as having an infinite half-life.

Table 5 presents the half-life estimates for both real official and parallel exchange rates of individual countries. Evidently, the empirical results show no systematic pattern for the country 
group as a whole. While the estimated half-life of the real parallel rate can differ significantly from that of the real official rate in a given country, there is no identifiable general pattern in the half-life difference between the two real rates. Interestingly, real parallel rates appear as likely to yield a shorter half-life as real official rates. In about half of the cases, real parallel rates may actually adjust more slowly rather than more quickly in comparison to real official rates. Qualitatively similar findings are obtained, regardless of whether the BW or the post-BW period is considered. Overall, there is no consistent evidence to support that greater exchange rate flexibility tend to generate faster or slower real exchange rate adjustment.

The foregoing analysis has been based on point estimates of half-lives. As discussed later, some recent studies (Cheung and Lai, 2000; Murray and Papell, 2002) investigate the potential uncertainty in estimating half-lives of real exchange rates. The allowance for uncertain half-life measurements will further reinforce our conclusion that there is little evidence of any systematic relationship between nominal exchange rate flexibility and the speed of real exchange rate adjustment.

\subsection{Departures from consensus estimates}

Previous studies of real exchange rates typically report slow adjustment speeds with halflives estimated to be 3 to 5 years. Describing the "consensus" on half-life estimates as remarkable and puzzling, Rogoff (1996) points out the difficulty in reconciling the slow adjustment speed of real exchange rates with their immense short-term volatility. Although standard exchange rate models with sticky prices may account for the huge short-term volatility under monetary shocks, the consensus half-life estimates are, as Rogoff (1996) notes, still too slow to be explained by nominal rigidities. On the other hand, the slow adjustment speed may reflect the influence of real shocks. If real shocks are predominant, they can exert significant long-lasting effects on the real exchange rate. Nevertheless, existing models based on real shocks cannot account for short-term exchange rate volatility.

The remarkable consensus highlighted by Rogoff (1996) comes mainly from real exchange rate studies of industrial countries. Departing from the consensus range, the half-life estimates obtained from the study here are much more dispersed. As shown in figure 1, the half-life estimates for both real official and parallel exchange rates show substantial variation among the 

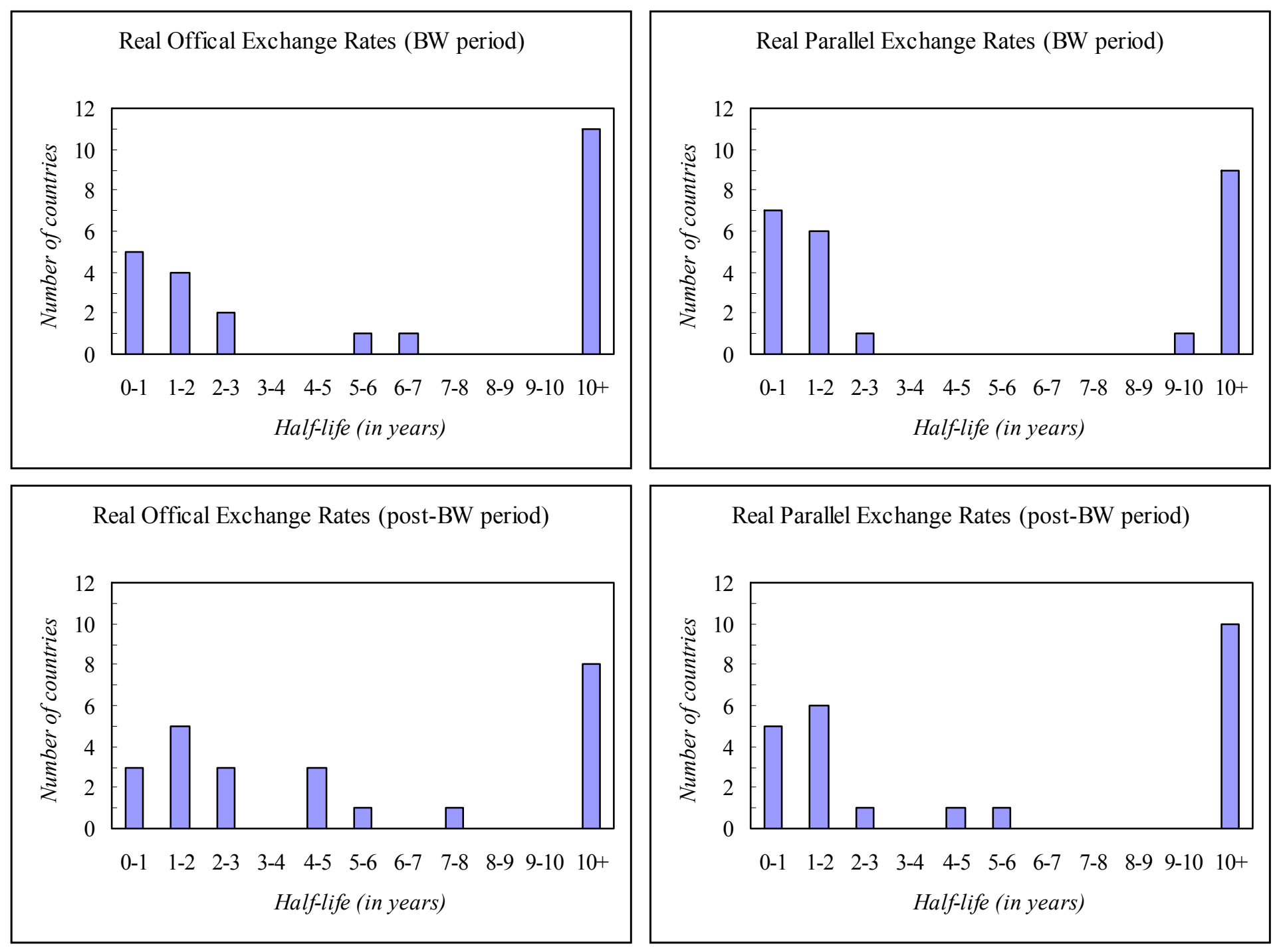

Figure 1. Cross-country differences in half-life estimates 
developing countries under study. In a large majority of cases, these half-life estimates fall far outside Rogoff's (1996) consensus range of 3-5 years. Indeed, the half-life estimates are as likely to be higher as to be lower than the previous consensus estimates. This applies to the BW and the post-BW period alike. For the BW period, the estimated half-lives of the real official and parallel rates are shorter than 2 years in 9 to 13 cases and longer than 6 years in 10 to 13 cases. For the post-BW period, the estimated half-lives of the real official and parallel rates are less than 2 years in 7 to 11 cases and more than 6 years in 9 to 10 cases.

All in all, the half-life consensus reported among previous studies on real exchange rates in industrial countries fails to prevail among developing countries, which display much greater heterogeneity. For a number of developing countries, the results may seem consistent with relatively fast adjustment speeds as suggested by sticky-price models. For other developing countries, the data may yield sluggish rates of real exchange rate adjustment that are so slow that there is little long-run reversion. These findings are robust with respect to whether the real official or the real parallel exchange rate is considered.

\subsection{Increased uncertainty in adjustment speed measurements}

In analyzing the speed of real exchange rate adjustment during the post-BW period, Cheung and Lai (2000) evaluate the sample half-life measure and its estimation accuracy. To quantify the inevitable imprecision with which the adjustment speed is estimated, confidence intervals for half-life estimates are computed for several major industrial countries. These confidence intervals are found to be wide, indicating a high level of uncertainty in measuring the half-life of real exchange rate adjustment. The lower-bound estimates generally come in with half-lives less than 2 years, but the upper-bound estimates contain half-lives that last 7 to 9 years. Murray and Papell (2002) examine the post-BW data from 20 industrial countries and find even greater uncertainty in half-life measurements. While the lower-end estimates can reach as low as just one year, the higher-end estimates are often infinitely large.

In this study we provide alternative evidence from the experience of developing countries with dual exchange rates over both the BW and post-BW periods. To explore whether the previous results on uncertain half-lives may similarly be observed in the data for developing countries, the $95 \%$ confidence interval for each individual half-life measurement is computed by 
Table 6. Sampling uncertainty in half-life estimates*

\begin{tabular}{|c|c|c|c|c|c|c|c|c|}
\hline \multirow[b]{3}{*}{ Country } & \multicolumn{4}{|c|}{ Bretton Woods } & \multicolumn{4}{|c|}{ Post-Bretton Woods } \\
\hline & \multicolumn{2}{|c|}{$\underline{\text { Real official rate }}$} & \multicolumn{2}{|c|}{ Real parallel rate } & \multicolumn{2}{|c|}{$\underline{\text { Real official rate }}$} & \multicolumn{2}{|c|}{ Real parallel rate } \\
\hline & $\overline{L B_{95 \%}}$ & $\overline{U B_{95 \%}}$ & $L B_{95 \%}$ & $\overline{U B_{95 \%}}$ & $\overline{L B_{95 \%}}$ & $\overline{U B_{95 \%}}$ & $L B_{95 \%}$ & $\overline{U B_{95 \%}}$ \\
\hline Argentina & {$[0.39$} & $\infty]$ & {$[0.71$} & $100+]$ & {$[0.31$} & $17.94]$ & {$[0.31$} & $100+]$ \\
\hline Bolivia & {$[0.63$} & 5.60] & {$[0.99$} & $\infty]$ & {$[0.10$} & $0.25]$ & {$[0.08$} & $\infty]$ \\
\hline Brazil & {$[0.30$} & $0.71]$ & {$[0.51$} & $100+]$ & {$[0.79$} & $17.07]$ & {$[0.45$} & $100+]$ \\
\hline Chile & {$[0.32$} & $0.81]$ & {$[33.32$,} & $\infty]$ & {$[100+$} & $\infty]$ & {$[0.89$} & $\infty]$ \\
\hline Colombia & {$[0.37$} & $100+]$ & {$[0.65$} & $2.10]$ & {$[3.78$} & $\infty]$ & {$[100+$} & $\infty]$ \\
\hline Costa Rica & {$[1.75$} & $100+]$ & {$[1.19$} & $2.38]$ & {$[0.23$} & $4.03]$ & {$[1.07$} & $100+]$ \\
\hline Dominican Republic & {$[0.24$} & $0.85]$ & {$[0.24$} & $0.53]$ & {$[0.55$} & $100+]$ & {$[0.94$} & $12.30]$ \\
\hline Ecuador & {$[0.55$} & $100+]$ & {$[1.71$} & $\infty]$ & {$[0.36$} & $\infty]$ & {$[0.99$} & $100+]$ \\
\hline Egypt & {$[0.80$} & $3.18]$ & {$[0.23$} & $0.64]$ & {$[0.63$} & $\infty]$ & {$[0.23$} & $12.98]$ \\
\hline El Salvador & {$[0.17$} & $\infty]$ & {$[0.62$} & $2.15]$ & {$[0.39$} & $3.46]$ & {$[0.40$} & $100+]$ \\
\hline India & {$[0.42$} & $1.24]$ & {$[0.33$} & $0.58]$ & {$[0.99$} & $9.93]$ & {$[0.61$} & 4.07] \\
\hline Israel & {$[0.50$} & $\infty]$ & {$[0.46$} & $2.40]$ & {$[1.41$} & $100+]$ & {$[0.18$} & $1.78]$ \\
\hline Korea & {$[0.44$} & $1.09]$ & {$[0.63$} & $2.14]$ & {$[0.59$} & $6.37]$ & {$[0.49$} & $3.62]$ \\
\hline Malaysia & {$[0.66$} & $2.54]$ & {$[0.47$} & $100+]$ & {$[1.07$} & $8.45]$ & {$[0.67$} & $12.18]$ \\
\hline Mexico & {$[1.47$} & $\infty]$ & {$[1.47$} & $\infty]$ & {$[1.02$} & $53.96]$ & {$[0.95$} & $100+]$ \\
\hline Morocco & {$[100+$,} & $\infty]$ & {$[0.22$} & $3.67]$ & {$[100+$} & $\infty]$ & {$[0.63$} & $\infty]$ \\
\hline Pakistan & {$[1.46$} & $\infty]$ & {$[0.24$} & $6.88]$ & {$[100+$} & $\infty]$ & {$[0.18$} & $12.09]$ \\
\hline Paraguay & {$[7.21$} & $\infty]$ & {$[1.64$} & $\infty]$ & {$[2.87$} & $\infty]$ & {$[6.93$,} & $\infty]$ \\
\hline Philippines & {$[0.77$} & $3.04]$ & {$[11.13$,} & $\infty]$ & {$[0.57$} & $12.58]$ & {$[0.46$} & $3.95]$ \\
\hline South Africa & {$[0.23$} & $86.31]$ & {$[0.27$} & $0.42]$ & {$[0.78$} & $100+]$ & {$[0.31$} & 23.29] \\
\hline Sri Lanka & {$[1.72$,} & $\infty]$ & {$[0.87$} & $\infty]$ & {$[0.23$} & $100+]$ & {$[1.20$} & $\infty]$ \\
\hline Thailand & {$[0.41$} & $0.98]$ & {$[0.48$} & $1.06]$ & {$[0.69$} & $6.70]$ & {$[0.35$} & $32.61]$ \\
\hline Uruguay & {$[0.24$} & $0.50]$ & {$[0.41$} & $1.26]$ & {$[1.23$} & $21.48]$ & {$[2.81$} & $\infty]$ \\
\hline Venezuela & {$[0.88$} & $\infty]$ & {$[0.35$} & $41.25]$ & {$[0.48$} & $100+]$ & {$[1.91$} & $\infty]$ \\
\hline
\end{tabular}

* All half-life estimates are expressed in years. For half-life estimates that are longer than 100 years, they are indicated by "100+" in the table. $\left[L B_{95 \%}, U B_{95 \%}\right]$ indicates the lower and upper bounds of the $95 \%$ confidence interval for the corresponding half-life estimate. 
Monte Carlo simulation. Using the estimated ARFIMA process for the respective data series as the data generating process, the half-life confidence interval is constructed based on 10,000 simulation replications in each case.

Table 6 gives the lower and upper bounds (denoted respectively by $L B_{95 \%}$ and $U B_{95 \%}$ ) of the half-life confidence interval. According to the lower-bound estimates, most half-lives can be as short as within a year for both real official and parallel rates. The upper-bound estimates of halflives, in contrast, show no general pattern. Unlike those estimates previously reported for industrial countries (Cheung and Lai, 2000; Murray and Papell, 2002), these upper-bound halflife estimates vary widely among developing countries, ranging from less than a year to infinitely many years.

A closer examination of our results suggests a possible difference in pattern between the BW and the post-BW period. Figure 2 summarizes the results on half-life uncertainty by looking at the relative width of half-life confidence intervals for each historical period. The interval width, which is the difference between $U B_{95 \%}$ and $L B_{95 \%}$, shows the level of uncertainty in estimating the half-life. A wider (narrower) confidence interval indicates greater (lesser) uncertainty. Compared to those for the BW period, the half-life confidence intervals for the post-BW period are more likely to be wider than to be narrower. This observed pattern holds for both real official and parallel exchange rates. For the post-BW data, in only one out of the 24 cases can the width of the half-life confidence interval be shorter than 3 years. For the BW data, in contrast, the width of the confidence interval can be less than 3 years in at least 10 cases.

The foregoing results raise interesting questions about the source of the increased uncertainty in measuring real exchange rate adjustment speeds. In our study, the post-BW sample period yields a larger number of observations than the BW sample period does. Although the width of the confidence interval depends partly on the sample size, the difference in sample size cannot account for the observed difference in the interval width between the two historical periods. For a given confidence level, the width of the confidence interval decreases, not increases, as the sample size grows. All else being equal, we should actually expect to see lower measurement uncertainty for the post-BW data than for the BW data. The empirical evidence shows just the opposite. Accordingly, the increased uncertainty may reflect the difference in variability of shocks rather than the difference in sample size. This suggests that some not yet identified factors can be responsible for the increased uncertainty in measuring real 

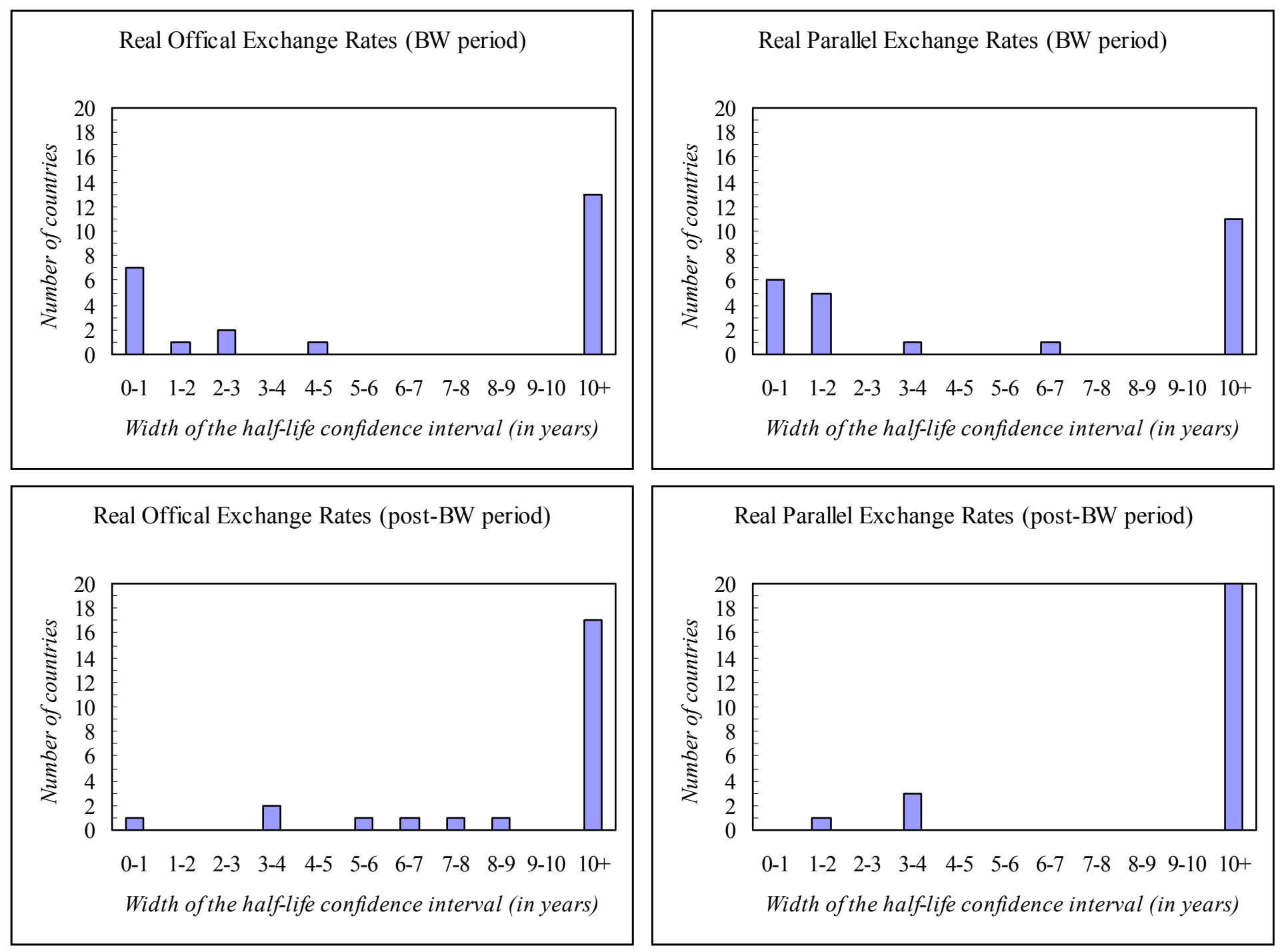

Figure 2. Cross-country variation in the uncertainty in half-life estimation 
exchange rate adjustment speeds during the post-BW period. This poses an interesting issue for future research.

\section{Further analysis of the cross-country variation in adjustment speeds}

With the estimated half-life of the real exchange rate varying greatly from country to country, it is instructive to investigate how much the observed cross-country variation is ascribable to inter-country differences in structural economic characteristics. We will examine several key country characteristics that have been identified in the literature as possible factors influencing real exchange rate dynamics. The first structural characteristic is the country's openness to trade. A basic element of the PPP adjustment process is that goods market arbitrage affects trade flows and induces real exchange rate adjustment. To ascertain whether openness to trade facilitates real exchange rate adjustment, the degree of trade openness is measured by the ratio of total trade (imports plus exports) to the country's GDP.

The second structural characteristic under study is the country's productivity growth. This supply-side factor is the focus of the Balassa-Samuelson hypothesis, which posits that productivity growth can induce sustained changes in real exchange rates due to its differential impact on the prices of traded and non-traded goods (Balassa, 1964; Samuelson, 1964). Empirical evidence for the hypothesis has been presented by, e.g., Canzoneri et al. (1999) and Chinn and Johnston (1999) based on OECD data.

Money growth is another country characteristic to be explored. A country's money growth rate is an indicator for the general stance of monetary policy: A lower (higher) rate of money growth means a tighter (easier) monetary policy. Unlike productivity changes, which are a source of real shocks, money supply changes represent monetary shocks. If nominal exchange rate and price changes are dominated by monetary rather than real shocks, real exchange rates are expected to adjust relatively fast. It is thus interesting to see if there is any significant negative relationship between half-lives of real exchange rates and money growth rates across countries.

The fourth country characteristic under consideration is government spending, a demandside factor included in some structural models of real exchange rates (e.g., Frenkel and Razin, 1996; Froot and Rogoff, 1991, Obstfeld and Rogoff, 1996). Unlike private spending, 
government spending tends to fall more heavily on non-traded goods. Consequently, government spending can affect the relative demand for - and thus the relative price of - traded and non-traded goods. Balvers and Bergstrand (2002) also highlight the complementarity of private and government consumption as an important channel through which government spending can influence the equilibrium real exchange rate. In addition to short-run effects, Alesina and Perotti (1995) show that government spending, if financed by distortionary taxes, can have long-run real effects. De Gregorio et al. (1994) examine panel data from OECD countries and report empirical evidence in support of a positive relationship between government spending and the relative price of traded and non-traded goods. Chinn and Johnston (1999) also find significant evidence from OECD data that government spending affects real exchange rates.

Table 7 shows the differences among the 24 developing countries in terms of structural economic characteristics. The trade openness variable represents the average ratio of total trade to GDP over the relevant sample period. For the productivity growth variable, the average annual rate of growth in real per capita GDP over the sample period is used as a broad proxy. The money growth variable measures the average annual rate of quasi money (M2) growth (adjusted for real GDP growth) over the sample period. The G/GDP growth variable gives the average annual rate of growth in government spending as a share of GDP over the sample period. In general, the cross-country data display huge variability in structural economic characteristics among the developing countries under study.

An inspection of the cross-country variation in either adjustment speeds or structural characteristics suggests that the usual distributional assumption on normality is not tenable for these data. This calls for the use of nonparametric methods in our statistical analysis. We first employ Spearman's rank correlation analysis to gauge the strength (and direction) of the relationship between the half-life of the real exchange rate and each structural economic variable. The rank correlation method makes no assumptions about the data distribution, and it does not require the underlying relationship between the variables to be linear. ${ }^{5}$ The rank-based method also works well when the data are not given in precise sample values.

To implement the Spearman analysis, all the observations are ranked from the smallest to

\footnotetext{
${ }^{5}$ The Pearson product-moment correlation coefficient, which is the standard correlation statistic, measures how well a linear equation describes the relation between two variables. The Spearman rank correlation coefficient, in contrast, measures how well an arbitrary monotonic function can describe the relationship between two variables. The monotonic function can be nonlinear.
} 
Table 7. Cross-country differences in structural economic characteristics

\begin{tabular}{|c|c|c|c|c|c|c|c|c|}
\hline \multirow[b]{2}{*}{ Country } & \multicolumn{4}{|c|}{ Bretton Woods } & \multicolumn{4}{|c|}{ Post-Bretton Woods } \\
\hline & $\begin{array}{l}\text { Trade } \\
\text { openness }\end{array}$ & $\begin{array}{l}\text { Productivity } \\
\text { growth }\end{array}$ & $\begin{array}{l}\text { Money } \\
\text { growth }\end{array}$ & $\begin{array}{l}\text { G/GDP } \\
\text { growth }\end{array}$ & $\begin{array}{l}\text { Trade } \\
\text { openness }\end{array}$ & $\begin{array}{l}\text { Productivity } \\
\text { growth }\end{array}$ & $\begin{array}{l}\text { Money } \\
\text { growth }\end{array}$ & $\begin{array}{l}\text { G/GDP } \\
\text { growth }\end{array}$ \\
\hline Argentina & 22.05 & 14.93 & 18.22 & -10.59 & 17.32 & 0.16 & 183.55 & -1.21 \\
\hline Bolivia & 43.58 & 3.25 & 22.45 & 1.70 & 47.70 & 0.13 & 94.72 & 1.35 \\
\hline Brazil & 13.57 & 6.03 & 43.28 & -1.33 & 17.65 & 1.52 & 266.31 & 3.01 \\
\hline Chile & 74.31 & 13.86 & 42.38 & 3.22 & 52.73 & 2.95 & 46.45 & -1.30 \\
\hline Colombia & 27.37 & 3.94 & 19.56 & 3.47 & 31.22 & 1.69 & 34.29 & 3.57 \\
\hline Costa Rica & 54.74 & 3.16 & 7.93 & 2.90 & 73.87 & 1.24 & 25.53 & -0.41 \\
\hline Dominican Republic & 39.62 & 2.72 & 14.66 & -2.81 & 64.02 & 1.97 & 17.29 & -0.88 \\
\hline Ecuador & 35.54 & 2.95 & 10.50 & -0.97 & 52.53 & 0.92 & 10.23 & -0.09 \\
\hline Egypt & 37.84 & N.A. & N.A. & 3.27 & 53.13 & 2.75 & 14.75 & -3.45 \\
\hline El Salvador & 51.78 & 2.32 & 7.66 & 0.06 & 57.62 & 0.41 & 10.95 & -0.45 \\
\hline India & 10.60 & 1.46 & 9.80 & 1.99 & 16.60 & 2.72 & 14.84 & 1.54 \\
\hline Israel & 65.06 & 4.61 & 0.71 & 4.56 & 91.06 & 2.10 & 61.91 & -1.36 \\
\hline Korea & 26.68 & 4.51 & 42.07 & -0.69 & 68.59 & 5.76 & 15.04 & 0.59 \\
\hline Malaysia & 87.13 & 7.01 & 11.50 & 1.96 & 130.66 & 3.97 & 9.95 & -1.87 \\
\hline Mexico & 20.59 & 3.32 & 9.46 & 4.43 & 34.16 & 1.21 & 38.72 & 0.54 \\
\hline Morocco & 42.52 & 1.22 & 9.72 & 0.13 & 50.04 & 1.52 & 14.67 & 1.70 \\
\hline Pakistan & 20.62 & 1.12 & 14.37 & 2.45 & 33.81 & 2.37 & 12.71 & 0.57 \\
\hline Paraguay & 30.80 & 1.89 & 24.79 & 0.17 & 54.74 & 1.53 & 22.47 & 1.70 \\
\hline Philippines & 30.23 & 1.78 & 10.91 & 1.51 & 59.56 & 0.62 & 19.25 & 1.66 \\
\hline South Africa & 52.29 & 2.19 & 6.55 & 2.15 & 50.56 & -0.40 & 11.81 & 1.74 \\
\hline Sri Lanka & 54.02 & 3.96 & 7.14 & -0.45 & 70.60 & 3.76 & 17.70 & -0.70 \\
\hline Thailand & 37.48 & 4.24 & 15.02 & 1.43 & 63.38 & 4.85 & 12.44 & 0.70 \\
\hline Uruguay & 26.35 & -0.24 & 35.45 & 1.51 & 39.70 & 2.18 & 63.65 & -0.74 \\
\hline Venezuela & 48.52 & 2.05 & 7.75 & 0.25 & 53.25 & -0.37 & 26.22 & -1.70 \\
\hline
\end{tabular}

All the above numbers are given in percent per year, and they represent average values over the corresponding sample period. 
the largest for each data series. In case when a tie in rank occurs, the observations involved are assigned the average value of the ranks they would receive as if they were in successive order. Considering a pair of variables, say $\left(x_{1}, x_{2}\right)$, the rank correlation statistic (denoted by $\rho$ ) is given by

$$
\rho=1-\frac{6 \sum_{j=1}^{N}\left[R\left(x_{1 j}\right)-R\left(x_{2 j}\right)\right]}{N\left(N^{2}-1\right)}
$$

where $N$ is the number of observations for each variable, $R\left(x_{1 j}\right)$ is the rank order of the $j$ th observation of variable $x_{1}$, and $R\left(x_{2 j}\right)$ is the rank order of the $j$ th observation of variable $x_{2}$. The null hypothesis of $\rho=0$ (i.e., of no correlation between the two variables) can be tested against the alternative hypothesis of $\rho \neq 0$. Based on the rank correlation estimates (not reported but available upon request), little correlation could be found in all but one case. In the exception case, a significantly negative correlation was found between the money growth rate and the halflife of the real official exchange rate. In all the other cases, the correlation estimates were either statistically insignificant or having ambiguous signs or both.

A more formal analysis of the cross-country data is performed using the multiple rank regression method. Similar to rank correlation analysis, rank regression analysis is based on the rank-ordered data instead of the original data. The regression equation includes the various economic factors as explanatory variables:

$$
H L_{j}=\zeta_{0}+\zeta_{1} O P E N_{j}+\zeta_{2} P_{R O D}+\zeta_{3} G O V T_{j}+\zeta_{4} M O N E Y_{j} \quad j=1,2, \ldots, N
$$

where $H L$ is the half-life of the real exchange rate of the corresponding country, $O P E N$ is the trade openness of the respective economy, $P R O D$ is the country's average productivity growth rate, GOVT is the average increase in government spending as a share of the country's GDP, and $M O N E Y$ is the average money growth rate (adjusted for real GDP growth) in the respective country.

Table 8 contains the results from rank regression analysis, and they are largely consistent with those from rank correlation analysis. The coefficients on the variables of trade openness, productivity growth, and government spending are all found to be statistically insignificant. Some of these coefficients may even have an ambiguous sign. For the money growth variable, the coefficient is statistically significant in the case involving the real official exchange rate. The negative coefficient in this case suggests that countries with higher money growth rates tend to 
have faster speeds of real exchange rate adjustment. ${ }^{6}$ However, this finding does not apply to the real parallel exchange rate, which yields a money growth coefficient of an incorrect sign, though it is statistically insignificant. In addition to the separate regressions conducted for the BW and the post-BW period, regressions were also run using pooled data from both BW and post-BW periods together, with a time-period dummy being included as well. Qualitatively similar results were obtained from the pooled data that only the money growth coefficient was found to be statistically significant.

Table 8. Multiple rank regression analysis of the cross-country differences in adjustment speeds

\begin{tabular}{|c|c|c|c|c|}
\hline & \multicolumn{2}{|c|}{ Bretton Woods } & \multicolumn{2}{|c|}{ Post-Bretton Woods } \\
\hline & Real official rate & Real parallel rate & Real official rate & Real parallel rate \\
\hline Trade Openness & $\begin{array}{l}-0.077 \\
(0.218)\end{array}$ & $\begin{array}{c}0.148 \\
(0.261)\end{array}$ & $\begin{array}{l}-0.347 \\
(0.257)\end{array}$ & $\begin{array}{l}-0.089 \\
(0.263)\end{array}$ \\
\hline Productivity Growth & $\begin{array}{l}-0.007 \\
(0.203)\end{array}$ & $\begin{array}{c}0.255 \\
(0.243)\end{array}$ & $\begin{array}{c}0.237 \\
(0.229)\end{array}$ & $\begin{array}{l}-0.038 \\
(0.235)\end{array}$ \\
\hline Government Spending & $\begin{array}{c}0.011 \\
(0.188)\end{array}$ & $\begin{array}{l}-0.032 \\
(0.225)\end{array}$ & $\begin{array}{l}-0.075 \\
(0.241)\end{array}$ & $\begin{array}{c}0.038 \\
(0.247)\end{array}$ \\
\hline Money Growth & $\begin{array}{l}-0.666 \\
(0.216)^{*}\end{array}$ & $\begin{array}{c}0.187 \\
(0.259)\end{array}$ & $\begin{array}{l}-0.125 \\
(0.231)\end{array}$ & $\begin{array}{c}0.217 \\
(0.237)\end{array}$ \\
\hline$R^{2}$ & 0.411 & 0.144 & 0.118 & 0.079 \\
\hline
\end{tabular}

The dependent variable is the adjustment speed measured in terms of the half-life of the real exchange rate. Standard errors of the coefficient estimates are given in parentheses. Statistical significance is indicated by an asterisk $\left({ }^{*}\right)$ for the $5 \%$ level.

In summary, the estimates of real exchange rate adjustment speeds show substantial variation across developing countries. These different speed estimates are generally found to differ from Rogoff's (1996) range of consensus estimates identified for industrial countries.

\footnotetext{
${ }^{6}$ The negative relationship found between the adjustment speed and the rate of money growth is consistent with previously reported findings that PPP holds particularly well for economies with high inflation rates (e.g., McNown and Wallace, 1989).
} 
Although the cross-country variation can be partially attributed to inter-country differences in money growth, much of the heterogeneity remains unaccounted for. This is certainly an area that warrants additional investigation in future research. ${ }^{7}$

\section{Concluding remarks}

A longstanding issue in exchange rate economics concerns whether greater exchange rate flexibility promotes real exchange rate adjustment. The latter represents an important channel through which an open economy adjusts to disturbances. Some economists consider nominal exchange rate flexibility to be important for macroeconomic adjustment by accelerating the realignment of the real exchange rate, while others hold the opposing view that free exchange rate movement may actually disrupt and prolong the real exchange rate adjustment process.

Instead of relying on inter-period comparisons of different exchange rate regimes, as previous studies of industrial countries have done, this study examines intra-period data on official and parallel exchange rates from developing countries. Specifically, it analyzes whether the flexible parallel market rate implies a faster speed of real exchange rate adjustment than the much less flexible official rate does. The use of the intra-period data on dual exchange rates averts the usual need to control for inter-period differences in economic conditions. With the official and parallel rates operating under same economic conditions, there is no significant evidence that greater exchange rate flexibility tends to produce faster or slower real exchange rate adjustment, although there is substantial heterogeneity in adjustment speed estimates across countries. In other words, based on the information from dual exchange rates, no systematic relationship can be found between nominal exchange rate flexibility and the speed of real exchange rate adjustment. The result holds for both the BW and the post-BW data.

Many developing countries have used parallel exchange markets as a tool to adjust to economic shocks and external imbalances. When official exchange rate adjustment is limited, changes in real exchange rates need to come mainly through price changes. In these countries where an official peg to the dollar is adopted, the presence of an active parallel exchange market offers a back-door channel that may help facilitate real exchange rate adjustment. Although

\footnotetext{
${ }^{7}$ A new study by Benigno (2004) illustrates how a country's choice of monetary policy rules may influence real exchange rate persistence.
} 
parallel exchange rates can move much more freely than official rates, parallel rate movements are, in most cases, not found to generate faster real exchange rate adjustment.

A final remark about the scope of our analysis is in order. The central question we examined is: If exchange rates were operating under same economic conditions, would a more flexible rate generally produce faster or slower real rate adjustment than a less flexible rate? We did not attempt to make any general inferences about the difference in the speed of real exchange adjustment between economies with fixed exchange rates and those with floating rates. Countries with different exchange rate systems usually differ considerably in economic conditions, which can cause different real exchange rate dynamics. Even among economies with a similar exchange rate system, there can be substantial variation in real exchange rate adjustment behavior. The developing countries examined in this study are characterized as having largely a fixed exchange rate under the official IMF classification, and yet these countries still yield a wide range of speed estimates for real exchange rate adjustment. Moreover, the de facto exchange rate regime can be very different from the officially stated regime. Reinhart and Rogoff (2004) observe that, when a parallel exchange market exists, a regime of an official peg might easily turn out to be a de facto float or a crawling band. All these empirical issues make a general determination of the regime effect rather difficult. This goes back to the reason why we do not analyze exchange rate flexibility in broader terms of exchange rate regimes (floating-rate regimes as opposed to fixed-rate regimes), but in more specific terms of dual exchange rates (market-determined parallel rates as opposed to pegged official rates). The latter approach provides a more controlled study of the adjustment dynamics of exchange rates with different flexibility. 


\section{References}

Alesina, A., and Perotti, R., 1995, Taxation and redistribution in an open economy, European Economic Review 39, 961-979.

Balassa, B., 1964, The purchasing power parity doctrine: A reappraisal, Journal of Political Economy 72, 584-596.

Balvers, R.J., and Bergstrand, J.H., 2002, Government spending and equilibrium real exchange rates, Journal of International Money and Finance 21, 667-692.

Benigno, G., 2004, Real exchange rate persistence and monetary policy rules, Journal of Monetary Economics 51, 473-502.

Booth, G.C. and Mustafa, C., 1991, Long-run dynamics of black and official exchange rates, Journal of International Money and Finance 10, 392-405.

Canzoneri, M.B., Cumby, R.E., and Diba, B., 1999, Relative labor productivity and the real exchange rate in the long run: evidence for a panel of OECD countries, Journal of International Economics 47, 245-266.

Cheung, Y.W., and Diebold, F.X., 1994, On maximum likelihood estimation of the differencing parameter of fractionally-integrated noise with unknown mean, Journal of Econometrics 62, 301-316.

Cheung, Y.W., and Lai, K.S., 1993, A fractional cointegration analysis of purchasing power parity, Journal of Business and Economic Statistics 11, 103-112.

Cheung, Y.W., and Lai, K.S., 2000, On the purchasing power parity puzzle, Journal of International Economics 52, 321-330.

Cheung, Y.W., Lai, K.S., and Bergman, M., 2004, Dissecting the PPP puzzle: the unconventional roles of nominal exchange rate and price adjustments, Journal of International Economics 64, 135-150.

Chinn, M., and Johnston, J., 1999, Productivity, government spending and the real exchange rate: evidence for OECD Countries. In: MacDonald, R., and Stein, J. (eds), Equilibrium exchange rates, Kluwer Academic, pp.163-190.

De Gregorio, J., Giovannini, A., and Wolf, H.C., 1994, International evidence on tradables and nontradables inflation, European Economic Review 38, 1225-1244.

Diamandis, P.F., 2003, Market efficiency, purchasing power parity, and the official and parallel markets for foreign currency in Latin America, International Review of Economics and Finance 12, 89-110.

Diebold, F.X., Husted, S., and Rush, M., 1991. Real exchange rates under the Gold Standard, Journal of Political Economy 99, 1252-1271.

Dornbusch, R., Dantas, D.V., Pechman, C., Rocha, R.D.R., and Simoes, D., 1983, The black market for dollars in Brazil, Quarterly Journal of Economics 98, 25-40. 
Engel, C., and Morley, J.C., 2001, The adjustment of prices and the adjustment of the exchange rate, NBER Working paper no. 8550.

Fox, R., and Taqqu, M.S., 1986, Large-sample properties of parameter estimates for strongly dependent stationary Gaussian time series, Annual of Statistics 14, 517-532.

Frenkel, J.A., and Razin, A., 1996, Fiscal policies and growth in the world economy. The MIT Press, Cambridge, MA.

Friedman, M., 1953, The case for flexible exchange rates. In: M. Friedman, Essays in Positive Economics. University of Chicago Press, Chicago, pp.157-203.

Froot, K.A., and Rogoff, K., 1991, The EMS, the EMU, and the transition to a common currency. In: Blanchard, O.J., and Fischer, S. (Eds.), 1991 NBER Macroeconomic Annual. The MIT Press, Cambridge, MA, pp. 269-317.

Ghei, N. and S.B. Kamin, 1999, The use of the parallel market rate as a guide to setting the official exchange rate. In: L.E. Hinkle and P.J. Montiel (eds), Exchange rate misalignment: concepts and measurement for developing countries. Oxford University Press, World Bank, pp. 497-538.

Granger, C.W.J. and R. Joyeux, 1980, An introduction to long-memory time series models and fractional differencing, Journal of Time Series Analysis 1, 15-39.

Hosking, J.R.M., 1981, Fractional differencing, Biometrika 68, 165-176.

Grilli, V., and Kaminsky, G., 1991, Nominal exchange rate regimes and the real exchange rate, Journal of Monetary Economic 27, 191-212.

Kamin, S., 1993, Devaluation, exchange controls, and black markets for foreign exchange in developing countries, Journal of Development Economics 40, 151-169.

Kouretas, G.P., and Zarangas, L.P., 1998, A cointegration analysis of the official and parallel foreign exchange markets for dollars in Greece, International Journal of Finance and Economics 3, 261-276.

McNown, R. and Wallace, M.S., 1989, National price levels, PPP, and cointegration: a test of four high-inflation economies, Journal of International Money and Finance 8, 533-545.

Montiel, P.J., and Ostry, J.D., 1994, The parallel market premium, IMF Staff Papers, 55-75.

Murray, C.J., and Papell, D.H., 2002, The purchasing power parity persistence paradigm, Journal of International Economics 56, 1-19.

Nurkse, R., 1944, International currency experience: lessons of the inter-war period, Geneva: League of Nations.

Obstfeld, M., and Rogoff, K., 1996, Foundations of international macroeconomics. The MIT Press, Cambridge, MA.

Pozo, S., and Wheeler, M., 1999, Expectations and the black market premium, Review of International Economics 7, 245-253. 
Phylaktis, K., 1991, The black market for dollars in Chile, Journal of Development Economics 37 , 155-172.

Phylaktis, K., 1996, Black market for foreign currency: a survey of theoretical and empirical issues, Financial Markets, Institutions and Instruments 5, 210-233.

Reinhart, C.M., and Rogoff, K., 2004, The modern history of exchange rate arrangements: a reinterpretation, Quarterly Journal of Economics 114, 1-48.

Rogoff, K., 1996, The purchasing power parity puzzle, Journal of Economic Literature 34, 647-668.

Samuelson, P.A., 1964, Theoretical notes on trade problems, Review of Economics and Statistics 46, 145-154.

Tanaka, K., 1999, The nonstationary fractional unit root, Econometric Theory 15, 549-82. 


\section{CESifo Working Paper Series}

(for full list see www.cesifo-group.de)

1449 Jerome L. Stein, The Transition Economies: A NATREX Evaluation of Research, April 2005

1450 Raymond Riezman, John Whalley and Shunming Zhang, Metrics Capturing the Degree to which Individual Economies are Globalized, April 2005

1451 Romain Ranciere, Aaron Tornell and Frank Westermann, Systemic Crises and Growth, April 2005

1452 Plutarchos Sakellaris and Focco W. Vijselaar, Capital Quality Improvement and the Sources of Growth in the Euro Area, April 2005

1453 Kevin Milligan and Michael Smart, Regional Grants as Pork Barrel Politics, April 2005

1454 Panu Poutvaara and Andreas Wagener, To Draft or not to Draft? Efficiency, Generational Incidence, and Political Economy of Military Conscription, April 2005

1455 Maurice Kugler and Hillel Rapoport, Skilled Emigration, Business Networks and Foreign Direct Investment, April 2005

1456 Yin-Wong Cheung and Eiji Fujii, Cross-Country Relative Price Volatility: Effects of Market Structure, April 2005

1457 Margarita Katsimi and Thomas Moutos, Inequality and Relative Reliance on Tariffs: Theory and Evidence, April 2005

1458 Monika Bütler, Olivia Huguenin and Federica Teppa, Why Forcing People to Save for Retirement may Backfire, April 2005

1459 Jos Jansen, The Effects of Disclosure Regulation of an Innovative Firm, April 2005

1460 Helge Bennmarker, Kenneth Carling and Bertil Holmlund, Do Benefit Hikes Damage Job Finding? Evidence from Swedish Unemployment Insurance Reforms, May 2005

1461 Steffen Huck, Kai A. Konrad and Wieland Müller, Merger without Cost Advantages, May 2005

1462 Louis Eeckhoudt and Harris Schlesinger, Putting Risk in its Proper Place, May 2005

1463 Hui Huang, John Whalley and Shunming Zhang, Trade Liberalization in a Joint Spatial Inter-Temporal Trade Model, May 2005

1464 Mikael Priks, Optimal Rent Extraction in Pre-Industrial England and France - Default Risk and Monitoring Costs, May 2005 
1465 François Ortalo-Magné and Sven Rady, Heterogeneity within Communities: A Stochastic Model with Tenure Choice, May 2005

1466 Jukka Pirttilä and Sanna Tenhunen, Pawns and Queens Revisited: Public Provision of Private Goods when Individuals make Mistakes, May 2005

1467 Ernst Fehr, Susanne Kremhelmer and Klaus M. Schmidt, Fairness and the Optimal Allocation of Ownership Rights, May 2005

1468 Bruno S. Frey, Knight Fever - Towards an Economics of Awards, May 2005

1469 Torberg Falch and Marte Rønning, The Influence of Student Achievement on Teacher Turnover, May 2005

1470 John Komlos and Peter Salamon, The Poverty of Growth with Interdependent Utility Functions, May 2005

1471 Hui Huang, Yi Wang, Yiming Wang, John Whalley and Shunming Zhang, A Trade Model with an Optimal Exchange Rate Motivated by Current Discussion of a Chinese Renminbi Float, May 2005

1472 Helge Holden, Lars Holden and Steinar Holden, Contract Adjustment under Uncertainty, May 2005

1473 Kai A. Konrad, Silent Interests and All-Pay Auctions, May 2005

1474 Ingo Vogelsang, Electricity Transmission Pricing and Performance-Based Regulation, May 2005

1475 Spiros Bougheas and Raymond Riezman, Trade and the Distribution of Human Capital, June 2005

1476 Vesa Kanniainen, Seppo Kari and Jouko Ylä-Liedenpohja, The Start-Up and Growth Stages in Enterprise Formation: The "New View" of Dividend Taxation Reconsidered, June 2005

1477 M. Hashem Pesaran, L. Vanessa Smith and Ron P. Smith, What if the UK had Joined the Euro in 1999? An Empirical Evaluation Using a Global VAR, June 2005

1478 Chang Woon Nam and Doina Maria Radulescu, Effects of Corporate Tax Reforms on SMEs' Investment Decisions under the Particular Consideration of Inflation, June 2005

1479 Panos Hatzipanayotou, Sajal Lahiri and Michael S. Michael, Globalization, CrossBorder Pollution and Welfare, June 2005

1480 John Whalley, Pitfalls in the Use of Ad valorem Equivalent Representations of the Trade Impacts of Domestic Policies, June 2005

1481 Edward B. Barbier and Michael Rauscher, Trade and Development in a Labor Surplus Economy, June 2005 
1482 Harrie A. A. Verbon and Cees A. Withagen, Tradable Emission Permits in a Federal System, June 2005

1483 Hendrik Hakenes and Andreas Irmen, On the Long-Run Evolution of Technological Knowledge, June 2005

1484 Nicolas Schmitt and Antoine Soubeyran, A Simple Model of Brain Circulation, June 2005

1485 Carsten Hefeker, Uncertainty, Wage Setting and Decision Making in a Monetary Union, June 2005

1486 Ondřej Schneider and Jan Zápal, Fiscal Policy in New EU Member States - Go East, Prudent Man!, June 2005

1487 Christian Schultz, Virtual Capacity and Competition, June 2005

1488 Yvan Lengwiler and Elmar Wolfstetter, Bid Rigging - An Analysis of Corruption in Auctions, June 2005

1489 Johannes Becker and Clemens Fuest, Does Germany Collect Revenue from Taxing Capital Income?, June 2005

1490 Axel Dreher and Panu Poutvaara, Student Flows and Migration: An Empirical Analysis, June 2005

1491 Bernd Huber and Marco Runkel, Interregional Redistribution and Budget Institutions under Asymmetric Information, June 2005

1492 Guido Tabellini, Culture and Institutions: Economic Development in the Regions of Europe, July 2005

1493 Kurt R. Brekke and Michael Kuhn, Direct to Consumer Advertising in Pharmaceutical Markets, July 2005

1494 Martín Gonzalez-Eiras and Dirk Niepelt, Sustaining Social Security, July 2005

1495 Alfons J. Weichenrieder, (Why) Do we need Corporate Taxation?, July 2005

1496 Paolo M. Panteghini, S-Based Taxation under Default Risk, July 2005

1497 Panos Hatzipanayotou and Michael S. Michael, Migration, Tied Foreign Aid and the Welfare State, July 2005

1498 Agata Antkiewicz and John Whalley, BRICSAM and the Non-WTO, July 2005

1499 Petr Hedbávný, Ondřej Schneider and Jan Zápal, A Fiscal Rule that has Teeth: A Suggestion for a 'Fiscal Sustainability Council' underpinned by the Financial Markets, July 2005 
1500 J. Atsu Amegashie and Marco Runkel, Sabotaging Potential Rivals, July 2005

1501 Heikki Oksanen, Actuarial Neutrality across Generations Applied to Public Pensions under Population Ageing: Effects on Government Finances and National Saving, July 2005

1502 Xenia Matschke, Costly Revenue-Raising and the Case for Favoring Import-Competing Industries, July 2005

1503 Horst Raff and Nicolas Schmitt, Why Parallel Trade may Raise Producers Profits, July 2005

1504 Alberto Bisin and Piero Gottardi, Efficient Competitive Equilibria with Adverse Selection, July 2005

1505 Peter A. Zadrozny, Necessary and Sufficient Restrictions for Existence of a Unique Fourth Moment of a Univariate GARCH(p,q) Process, July 2005

1506 Rainer Niemann and Corinna Treisch, Group Taxation, Asymmetric Taxation and Cross-Border Investment Incentives in Austria, July 2005

1507 Thomas Christiaans, Thomas Eichner and Ruediger Pethig, Optimal Pest Control in Agriculture, July 2005

1508 Biswa N. Bhattacharyay and Prabir De, Promotion of Trade and Investments between China and India: The Case of Southwest China and East and Northeast India, July 2005

1509 Jean Hindriks and Ben Lockwood, Decentralization and Electoral Accountability: Incentives, Separation, and Voter Welfare, July 2005

1510 Michelle R. Garfinkel, Stergios Skaperdas and Constantinos Syropoulos, Globalization and Domestic Conflict, July 2005

1511 Jesús Crespo-Cuaresma, Balázs Égert and Ronald MacDonald, Non-Linear Exchange Rate Dynamics in Target Zones: A Bumpy Road towards a Honeymoon - Some Evidence from the ERM, ERM2 and Selected New EU Member States, July 2005

1512 Yin-Wong Cheung and Kon S. Lai, Nominal Exchange Rate Flexibility and Real Exchange Rate Adjustment: Evidence from Dual Exchange Rates in Developing Countries, July 2005 